\title{
The Prokinetic Effect of Mosapride Citrate on Horse Gastric Emptying Rates
}

\author{
Koichi OKAMURA ${ }^{l)}$, Naoki SASAKI ${ }^{2) *}$, Morito FUKUNAKA ${ }^{2)}$, Haruo YAMADA ${ }^{2)}$ and Hisashi INOKUMA $^{2)}$ \\ ${ }^{1)}$ The United Graduate School of Veterinary Sciences, Gifu University, 1-1 Yanago, Gifu-shi 501-1193 and ${ }^{2)}$ Department of Clinical \\ Veterinary Science, Obihiro University of Agriculture and Veterinary Medicine, Inada, Obihiro, Hokkaido 080-8555, Japan
}

(Received 5 April 2007/Accepted 12 February 2008)

ABSTRACT. The prokinetic effect of the 5- $\mathrm{HT}_{4}$ receptor agonist mosapride was evaluated in seven healthy thoroughbreds. Mosapride was orally administerd at doses of $0.5,1.0$ or $1.5 \mathrm{mg} / \mathrm{kg}$. The breath ${ }^{13} \mathrm{CO}_{2} /{ }^{12} \mathrm{CO}_{2}$ rate $\left(\Delta^{13} \mathrm{CO}_{2}\right)$, an indirect indicator for the rate of gastric empting, was measured at appropriate points for $4 \mathrm{hr}$ after drug administration. There was a significant increase compared with the control value at 15,20 and $165 \mathrm{~min}$ for $0.5 \mathrm{mg} / \mathrm{kg}, 30 \mathrm{~min}$ at $1.0 \mathrm{mg} / \mathrm{kg}$ and $165 \mathrm{~min}$ for $1.5 \mathrm{mg} / \mathrm{kg}$. The results suggest that mosapride may facilitate the gastric emptying in horses.

KEY WORDS: equine, gastric emptying rate, mosapride citrate.

J. Vet. Med. Sci. 70(6): 627-628, 2008

Gastric emptying is delayed in horses with various gastrointestinal disorders including chronic or recurrent colic $[2,6-8]$ as well as postoperative ileus [1]. Delayed gastric emptying may not be only a consequence of these disorders but also may cause them. It actually dose cause anorexia and abdominal discomfort/pain, aggravating gastrointestinal disorders. A variety of prokinetic agents, including metoclopramide and cisapride, have been administered to horses in order to coordinate gastrointestinal motility $[4,9]$, although they may produce unfavorable side effects on both the central nervous and cardiovascular systems [14]. Evidence has suggested that mosapride citrate (mosapride), a 5$\mathrm{HT}_{4}$ receptor-preferring agonist, is a more promising prokinetic $[30,15]$. This agent dose not interact with central dopamine receptors and hardly has any extrapyramidal side effects. It also has little activity in blocking cardiac $\mathrm{K}^{+}$ channels and produces no significant ventricular arrhythmia with prolonged QT intervals $[3,10]$. However, the effect of mosapride on gastric emptying in horses has yet to be investigated.

To do this, we used seven healthy thoroughbreds to examine the effect of orally-administrated mosapride on the rate of solid-phase gastric emptying using the ${ }^{13} \mathrm{C}$-octanoate breath test.

The animals used ( 1 mare and 6 geldings) had an average age of $5.6 \pm 2.6$ years (mean \pm SD: $n=7$ ) and a mean body weight of $485.7 \pm 46.9 \mathrm{~kg}(\mathrm{n}=7)$. They were fed an ordinary diet $(0.9 \mathrm{~kg}$ oats, $0.3 \mathrm{~kg}$ bran and $3.5 \mathrm{~kg}$ hay) twice daily and were allowed ad libitum access to water. The individual horses were each subjected to the breath test repeatedly at intervals of 7 to 9 days. Housing and care of the horses and the present study were in accordance with the protocol approved by the institutional animal care and use committee of Obihiro University.

Breath samples were collected via a silicon tube inserted

\footnotetext{
* Correspondence to: SASAKI, N., : Department of Clinical Veterinary Science, Obihiro University of Agriculture and Veterinary Medicine, Inada, Obihiro, Hokkaido 080-8555, Japan. e-mail: naoki@obihiro.ac.jp
}

into the ventral nasal meatus, as described previously [12], and into zoo or $1,300 \mathrm{~m} l \mathrm{UBit}^{\mathbb{R}}$-specialized breath sampling bags (Otsuka Pharmaceutical, Japan). The test meal consisted of $150 \mathrm{~g}$ oats, $100 \mathrm{~g}$ bran ( $200 \mathrm{~mL}$ in volume) and 500 mg $1{ }^{3} \mathrm{C}$-octanoate $\left(1-{ }^{13} \mathrm{C}\right.$ sodium octanoate, $99 \%$; Wako Pure Chemical Industries, Japan) in 2 baked egg yolks. The test meal was ingested voluntarily.

Mosapride (GASMOTIN ${ }^{\circledR}$ Powder 1\%) was purchased from Dainippon Sumitomo Pharma Co., Ltd. (Osaka, Japan). Following overnight fasting (12 hr), the drug was dissolved in $1,000 \mathrm{~mL}$ distilled water and administered at a dose of 0.5 to $1.5 \mathrm{mg} / \mathrm{kg}$ through a nasogastric tube. As a control, 1,000 $\mathrm{mL}$ distilled water alone was administered in a similar manner. Thirty minutes after drug administration, the test meal was given. Breath samples were collected into four $1,300 \mathrm{~mL}$ bags before administration and then into 200 $\mathrm{mL}$ bags at different times ( 5 to $240 \mathrm{~min}$ ) after the test meal (see Fig. 1). The samples collected were analyzed using a

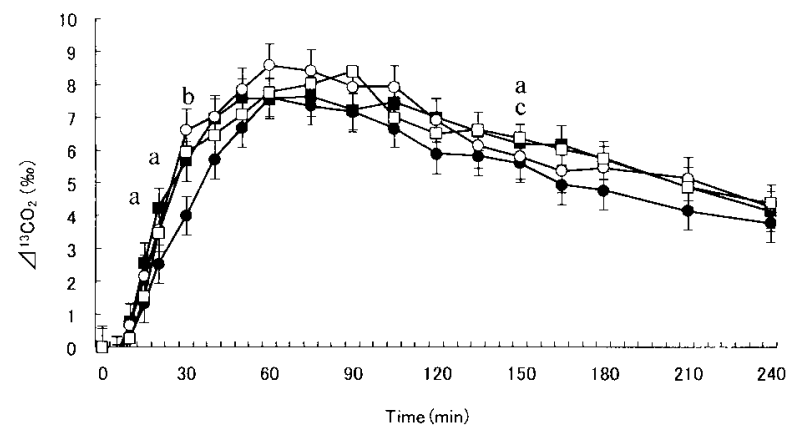

Fig. 1. Mean values of $\Delta^{13} \mathrm{CO}_{2}(\%) \pm$ SD of breaths collected over the 4-hr test period, following solid test food intake and mosapride administration at doses of $0.5 \mathrm{mg} / \mathrm{kg}(\boldsymbol{\square}, \mathrm{n}=7), 1.0$ $\mathrm{mg} / \mathrm{kg}(\bigcirc, \mathrm{n}=7)$ and $1.5 \mathrm{mg} / \mathrm{kg}(\square, \mathrm{n}=6)$. 0 : control (without drug administration, $\mathrm{n}=7$ ). One-way repeated measures ANOVA and Fisher's PLSD was used to determine significant differences between values. a: Significantly $(p<0.05)$ different between $0 \mathrm{mg}$ and $0.5 \mathrm{mg}$, b: Significantly $(\mathrm{p}<0.05)$ different between $0 \mathrm{mg}$ and $1.0 \mathrm{mg}$, c: Significantly $(\mathrm{p}<0.05)$ different between $0 \mathrm{mg}$ and $1.5 \mathrm{mg}$. 
${ }^{13} \mathrm{CO}_{2}$-infrared spectrophotometry analyzer (POC One ${ }^{\circledR}$, Otsuka Pharmaceutical, Japan). The excretion of ${ }^{13} \mathrm{C}$ was expressed as the difference $\left(\Delta^{13} \mathrm{CO}_{2}, \%\right.$ o $)$ between the ${ }^{13} \mathrm{CO}_{2} /$ ${ }^{12} \mathrm{CO}_{2}$ ratios before and after test meal administration. The assay system used was valid only when the $\mathrm{CO}_{2}$ concentration in the breath sample was above $0.5 \%$. The time when $\Delta^{13} \mathrm{CO}_{2}$ reached the maximum was regarded as the time of peak excretion $\left(\mathrm{t}_{\max }\right)$. If there were multiple peaks for $\Delta^{13} \mathrm{CO}_{2}$, the earliest one was taken as the $\mathrm{t}_{\max }$.

The results are presented as means \pm SD. One-way repeated measures ANOVA was used to determine significant differences between values. When a significant difference was found, a post-hoc test (Fisher's PLSD) was performed for further evaluation. Differences were considered significant when $\mathrm{P}<0.05$.

During the ${ }^{13} \mathrm{C}$-octanoated breath tests, none of the horses had any abnormal clinical signs, such as colic, sweating and agitation. Figure 1 shows plots of the rate of breath $\Delta^{13} \mathrm{CO}_{2}$ (\%o) against the time after administration of mosapride at $0.5,1.0$ or $1.5 \mathrm{mg} / \mathrm{kg}$. The breath $\Delta^{13} \mathrm{CO}_{2}$ of the drug-treated groups increased more rapidly and decreased more slowly, compared with that for the control group. Significantly higher rates $(\mathrm{p}<0.05)$ than the control value were observed at 15,20 , and $165 \mathrm{~min}$ with $0.5 \mathrm{mg} / \mathrm{kg}$ mosapride, at $30 \mathrm{~min}$ with $1.0 \mathrm{mg} / \mathrm{kg}$ mosapride, and at $165 \mathrm{~min}$ with $1.5 \mathrm{mg} / \mathrm{kg}$ mosapride.

The breath $\Delta^{13} \mathrm{CO}_{2}$ was determined by measuring the ${ }^{13} \mathrm{C}$ levels of breath samples hourly. It has previously been described as fluctuating depending on changes in the rate of duodenum absorption, liver metabolization, lung excretion or gastric emptying [5]. It is possible that the breath $\Delta^{13} \mathrm{CO}_{2}$ may preferentially reflect changes in the rate of gastric emptying [5]. Thus, the increases in breath $\Delta^{13} \mathrm{CO}_{2}$ observed with oral administration of mosapride may suggest that this drug has a facilitating effect on gastric emptying in horses. In addition, it is generally considered that the $t_{\max }$ measured for the breath $\Delta^{13} \mathrm{CO}_{2}$ is reached before the ${ }^{13} \mathrm{C}$ gastric emptying rate increases [11], and thus it is possible that the facilitating effect of mosapride lasts longer than expected from the $\mathrm{t}_{\max }$ for the breath $\Delta^{13} \mathrm{CO}_{2}$.

However, there was no eminent dose-dependence for the mosapride effect. Furthermore, significant increases in the breath $\Delta^{13} \mathrm{CO}_{2}$ by mosapride only occurred at limited time points after oral administration. Further studies are needed to establish the facilitating effect of mosapride on gastric empting. Mosapride is a selective $5-\mathrm{HT}_{4}$ receptor agonist, but no evidence has been provided for the distribution of 5$\mathrm{HT}_{4}$ receptors in the horse stomach. Further studies are needed again to elucidate the mechanism underlying the mosapride effect found in the present study.

The present results indicate the possibility that oral administration of mosapride facilitates gastric emptying of solid food in healthy horses and that it might be promising as a prokinetic agent for horses with delayed gastric emptying.

\section{REFERENCES}

1. Dart, A. J. and Hodgson, D. R. 1998. Aust. Vet. J. 76: 25-31.

2. Hillyer, M. H. and Mair, T. S. 1997. Equine Vet. J. 29: 421424.

3. Kii, Y., Nakatsuji, K., Nose, I., Yabuuchi, M., Mizuki, Y. and Ito, T. 2001. Pharmacol. Toxicol. 89: 96-103.

4. Koenig, J. and Cote, N. 2006. Can. Vet. J. 47: 551-559.

5. Maes, B. D., Hiele, M. I., Geypens, B. J., Rutgeerts, P. J., Ghoos, Y. F. and Vantrappen, G. 1994. Gut 35: 333-337.

6. Mair, T. S. and Hillyer, M. H. 1997. Equine Vet. J. 29: 415420.

7. McKenzie, E. C., Mills, J. N. and Bolton, J. R. 1997. Aust. Vet. J. 75: 480-483.

8. Milne, E. M., Doxey, D. L., Woodman, M. P., Cuddeford, D. and Pearson, R. A. 1996. Br. Vet. J. 152: 537-549.

9. Nieto, J. E., Rakestraw, P. C., Snyder, J. R. and Vatistas, N. J. 2000. Am. J. Vet. Res. 61: 413-419.

10. Potet, F., Bouyssou, T., Escande, D. and Baró, I. 2001. Gastrointestinal prokinetic drugs have different affinity for the human cardiac human ether-à-gogo $\mathrm{K}(+)$ channel. J. Pharmacol. Exp. Ther. 299: 1007-1012.

11. Sanaka, M., Yamamoto, T. and Kuyama, Y. 2005. Dig. Dis. Sci. 50: 669-670.

12. Sasaki, N., Aiuchi, H. and Yamada, H. 2005. J. Vet. Med. Sci. 67: 993-997.

13. Sasaki, N., Okamura, K. and Yamada, H. 2005. Am. J. Vet. Res. 66: 1321-1323.

14. Tonini, M., Cipollina, L., Poluzzi, E., Crema, F., Corazza, G. R. and De Ponti, F. 2004. Aliment. Pharmacol. Ther. 19: 379390.

15. Yoshida, N. 1999. Nippon Yakurigaku Zasshi 113: 299-307. 